\title{
New perspective of film tourism: a comparative study (2014-2020)
}

\author{
Janire Domínguez-Azcue \\ janire@uma.es \\ Faculty of Tourism, Campus of Teatinos, University of Malaga. \\ Fernando Almeida-García \\ falmeida@uma.es \\ Tourism Intelligence and Innovation Research Institute, Faculty of Tourism, Campus of Teatinos, \\ University of Malaga \\ Gema Pérez-Tapia \\ gema.perez@uma.es \\ Faculty of Commerce and Management, Campus of Teatinos, University of Malaga

\section{Pere Mercadé-Melé} \\ pmercade@uma.es \\ Faculty of Economic Science, Department of Statistics and Econometrics, Campus of El Ejido, \\ University of Malaga
}

\section{Abstract}

This study aims to compare film tourism and their activities, before and during the CoViD19 pandemic. For this purpose, a comparative analysis is carried out between 2014 and 2020, the latter date being affected by the pandemic caused by Covid-19. This study is based on 888 surveys between the mentioned two years, distributed mainly among respondents from Europe and the United States. The results of the research indicate that there are no changes concerning the knowledge of the film tourism term, but differences are observed in the study period regarding the activities linked to this type of tourism, as well as to motivations and 
travel intentions driven by films or series. Lastly, changes in the popularity or knowledge of film destinations were observed during the study period. The findings of this research are particularly useful for destination managers.

Keywords: Film tourism; film-induced tourism; film destinations; marketing; tourism development; DMOs; Covid-19

\section{Introduction}

Cultural tourism is a typology of tourism through which individuals get to know and learn about different lifestyles and societies. In the same way, cultural factors are the means by which a destination presents itself to visitors, through gastronomy, architecture, music or leisure activities. Since film is part of artistic and cultural expression, but also part of the entertainment industry, film tourism can be placed under the umbrella of cultural tourism (McKercher \& Cross, 2002; Hudson \& Ritchie, 2006).

Film tourism has been very successful in the last decade. In recent years, numerous studies have been carried out on this type of tourism, from very diverse fields such as psychology (Hao \& Ryan, 2013; Martin-Jones, 2014; Rittichainuwat \& Rattanaphinanchai, 2015), marketing (Hudson \& Ritchie, 2006; O'Connor, Flanagan \& Gilbert, 2008) or economics (Croy, 2011; Li, Li, Song, Lundberg, \& Shen, 2017), among others. Those studies have also been approached from different perspectives and methodologies and with very different objectives, such as highlighting the benefits of film tourism (Kim, Kim \& King, 2018), its negative aspects (Pratt, 2015), case studies of a specific destination (Hudson \& Ritchie, 2006; Tkalec, Zilic \& Recher, 2017), or a review of the literature in this field (Domínguez-Azcue, Almeida-García, Pérez-Tapia \& Cestino-González, 2021). However, there is a lack of studies on the evolution of film tourism that show how it has evolved in recent years and help us understand in which direction it is heading.

The objective of this research is to present the situation of film tourism and its development in recent years (2014-2020). This research describes the development of film tourism in the last years and provides useful information for destination managers and DMOS to use when defining strategies for film destinations. The main contribution of this paper is to propose a 
comparative analysis on film tourism from the situation in 2014 and today, based on a survey that was first conducted in 2014 and then again in 2020, when a global pandemic occurred due to COVID-19. That new situation has completely changed tourism in general, and film destinations in particular (Liu, Chin, Nechita \& Candrea, 2020). We consider that this event may mark a before, and after which makes it necessary to analyse it. Moreover, in the main databases (WOS, RSCI, SCIELO, MEDLINE, CCC, DIIDW, KJD) there is no research related to film tourism and COVID-19 - to date, only the one by Liu et al. (2020) has been found. Therefore, it is necessary to investigate the impact of the pandemic on film tourism.

The literature analysis section reviews the evolution of film tourism in recent years and the role of destination managers and DMOs in this regard. The next section sets out the methodology used in the research, as well as giving information on the questionnaire design and the description of the sample. The fourth section presents the results obtained from the methodological analyses. The discussion and conclusions delve into the discussion of such findings and draw some conclusions on the growing importance of the relationship between films and tourism, and on the key role of tourism managers and DMOs.

\section{Literature Review}

\subsection{From tourism and films to film tourism}

Since the 1990s, academic literature on tourism induced by films has demonstrated the relationship between the presence of certain destinations or places in films and TV series and the increase in the number of visitors to them (Riley \& Van Doren, 1992; Grihault, 2003). Destination image plays a fundamental role in this regard since destination images have a decisive influence on people's travel decision (Butler, 1990; Shani, Wang, Hudson \& Gil, 2009). This destination image is a multidimensional construction in which information sources are decisive (Um \& Crompton, 1990; Baloglu, 2000; Eagles, 2000; Bieger \& Laesser, 2004; Almeida-García, Domínguez-Azcue \& Mercadé-Melé, 2017). Among these sources, films and series fall under the category of autonomous information sources, which are very influential and credible and are not perceived by individuals as invasive and aggressive, unlike other information sources such as conventional TV commercials or traditional advertising (Gartner, 1993; Avery \& Ferraro, 2000; Russel, 2002). Autonomous sources provide a wealth of information about a destination in a very short period and, therefore, they 
can create an image for the first time or alter a previous image rapidly (Kim \& Richardson, 2003). In this regard, the effect that films and series can have on potential tourists is highly important (Hahm, Upchurch \& Wang, 2008).

This leads to a specific tourism typology: film tourism. Film tourism - also known as filminduced tourism or movie-induced tourism - is a quite recent concept. However, this type of tourism has a long tradition, and it has been studied from different perspectives and in different fields, such as marketing (Riley \& Van Doren, 1992; Hudson \& Ritchie, 2006; O'Connor, Flanagan \& Gilbert, 2008), sociology or psychology (Hao \& Ryan, 2013; MartinJones, 2014; Rittichainuwat \& Rattanaphinanchai, 2015), among others. Thus, film tourism is a multidimensional concept, and it is informed by several cross-disciplinary perspectives (Connell, 2012).

Despite being a quite new concept, in the last decade, the knowledge of film tourism has increased considerably, as evidenced by the growing number of research that have been carried out in this field (Beeton \& Cavicchi, 2015; Cardoso, Estêvão, Fernandes \& Alves, 2017; Domínguez-Azcue, et al., 2021).

Recent studies by Domínguez-Azcue et al. (2021) point out that there has been a notable increase in research related to film tourism (between 2010 and 2020, 39.3\% of studies have been carried out). There is a trend towards growth in studies related to social networks, series, media and marketing, although analyses of film destinations predominate. Other recent general reviews agree in highlighting the importance of destinations related to image and destination marketing and the impacts of film tourism, as well as highlighting the strong interest in this type of studies in Asia (Nakayama, 2020). This author himself points out the dynamism that Asia is experiencing in this field while maintaining the importance of the Korean Wave (Lee, 2021; Ng \& Chan, 2020; Bang, Joo, Seok \& Nam, 2021). Some studies highlight the role of television operators and consumption analysis using algorithms (Blanchet \& Fabry, 2020) or the impact on specific tourism products such as gastronomic tourism (Xu, Kim \& Reijnders, 2020).

It could be thought that this growing academic interest is accompanied by a better understanding of film tourism by tourists since generally academia and society tend to go hand in hand. It is even possible that the familiarity with the term "film tourism" itself has not 
changed, but that tourists' behaviour has changed because of the influence of a film or series. Before examining the evolution of activities associated with film tourism or its motivations, it is necessary to study the possible variation in knowledge of the term "film tourism", i.e., whether knowledge of the term has increased or decreased over time, to analyse the following hypotheses. Based on this consideration, Hypothesis 1 is therefore proposed, which aims to test this statement:

H1: Knowledge of the term "film tourism" has changed over the study period.

Since it is a relatively new type of tourism and susceptible to being associated with different activities, it is necessary to know to what extent respondents associate it with those activities and how it has evolved. The rise of social networks may have fostered a change in the tendencies of tourists when visiting a place (Domínguez-Azcue et al., 2021). That is of interest especially for destination management since it will be possible to have a greater impact on those activities that are more strongly associated with film tourism (DomínguezAzcue et al., 2021). Film tourism can be related to or associated with different activities. Identifying the activities that are most closely related to film tourism provides valuable knowledge for DMOs, as it allows them to better design the marketing strategy by focusing the product design and its activities on the activities that generate the greatest impact and attraction.

It might seem evident that film tourism is related only to filming locations. However, numerous papers associate it with other film-related activities, although not strictly with locations where filming takes place. Some researchers associate this concept with the cities where celebrities live (Chen, 2018; Kim, Kim and Han, 2019), or with the places where film festivals take place (Özdemir \& Adan, 2014) and even with film studios (Beeton, 2005).

Hypothesis 2 is proposed based on the different activities with which this type of tourism is related and with a twofold objective - to find out which activity is associated with greater intensity and how it has evolved in recent years:

H2: The activities associated with film tourism have changed over the study period.

When talking about film tourism most authors agree that this term includes both film and TV series-induced tourism (Cardoso, et al., 2017) and include it under the umbrella of cultural 
tourism (Hudson \& Ritchie, 2006; Martin-Fuentes, Nieto-Ferrando, Marine-Roig \& FerrerRosell, 2020), since cultural tourism is a tourism typology through which tourists learn about different societies, cultures and lifestyles, and films and series are part of the artistic and cultural expression of those places (Gyimóthy, Lundberg, Lindström, Lexhagen \& Larson, 2015).

Film tourists travel to the destination in order to see in person the places they have previously seen on the screen (Roesch, 2009). Sometimes it can be an important and renowned place also visited by cultural tourists in general, but at other times these tourists go one step further, and they do not visit just places that are part of the cultural heritage of the destination, but also lesser-known places that may not have an important cultural value for cultural tourists in general, such as bars, benches, parks or private houses where films and TV series have been filmed. Therefore, film tourism is related to a special tourist interest, and the specific motivation of tourists differentiates it from other tourism typologies. One of its main features is that this type of tourism does not focus on a specific group of individuals, but every film and TV series has its own group of individuals and these groups can be very different and with different characteristics (Papathanassis, 2011).

Regarding individual tourists' motivations for visiting film-related sites, Macionis (2004) establishes a continuum of increasing interest and distinguishes between three types of film tourists: "Serendipitous tourists", who just happen to be in a destination where a film or series was shot; "General tourists" who are not specifically drawn to a film location, but participate in film tourism activities once they are there; and "Specific tourists", who actively seek out places seen in films and series and demand a deep film experience (Figure 1).

Figure 1. Continuum of Film-induced motivation

\begin{tabular}{lll}
\hline Increasing interest in film & \\
\hline Serendipitous & General & Specific \\
Film tourist & Film tourist & Film tourist \\
Those who just & Those who are not Those who actively seek \\
happen to be in a specifically drawn to a film out places that they \\
destination portrayed location but who participate have seen in film \\
in a film & $\begin{array}{l}\text { in film tourism activities } \\
\text { while at a destination }\end{array}$ \\
\hline
\end{tabular}

Source: Macionis, 2004 
A subgroup within "Specific tourists" could be added, since while the aforementioned tourists aim to visit film-related places, they also participate in more general tourism activities and they also visit other tourist attractions that are not film-related. This is why Connell and Meyer (2009) suggest the subcategory "Elite tourists" within "Specific tourists". The sole purpose of this type of tourist is to visit film-related sites and they do not visit other tourist attractions. This type of tourist is more likely to buy film-related souvenirs and return to the destination in the future (Connell \& Meyer, 2009; Rittichainuwat \& Rattanaphinanchai; 2015). The modifications in the motivations and behaviours of film tourists invite their analysis, which is why the following hypothesis is proposed:

H3: Film tourists' motivation to travel because of watching a film or series has changed over the study period.

In the literature, two concepts are frequently related: motivations and visit intention. There are authors (Li \& Cai, 2012; Jang, Bai, Hu, \& Wu, 2009; Yoon \& Uysal 2005) who defend that there is a very close relationship between the two, to the extent that they suggest that motivation is a predictor of future behaviour or intentions. Other studies, however, fail to support the relationship between the two variables (Ramkissoon \& Uysal 2011; Li, Cai, Lehto \& Huang, 2010).

In the context of film tourism, previous research highlights the role of media in shaping motivations to visit a destination (Macionis, 2004). Films can awaken the desire to visit a destination, since they are organic agents of the destination image (Kim and Richardson, 2003) and are considered by viewers as a source of unbiased information, unlike traditional advertising (Schofield, 1996). Similarly, previous research studies have analysed and confirmed the relationship between place attachment and the intention to visit (Hosany, Buzova \& Sanz-Blas, 2020), revisit and recommend a film destination (Wong \& Lai, 2015).

Given the importance of the intention to visit a destination in the final decision of the traveller, it is important to know what influence films have on the intention to visit. In the same way, it is also fundamental to measure how this predisposition to the visit has evolved over the last few years. In addition, given the relationship between motivations and intention to visit, it is essential to know if they have evolved in the same direction. In this context, the following research hypothesis is proposed: 
H4: The influence of films and series on the travel intention has changed over the study period.

\subsection{Film destinations, destination managers, and DMOs}

Films and TV series have become powerful tourist motivators. The fact that a destination appears in a film can arouse the interest of many potential tourists. In this context, the role of DMOs, Film Commissions, and destination managers is fundamental. Destination managers are aware of the growingly important role of films and TV series when it comes to increasing the number of tourists to a destination (Connell \& Meyer, 2009). Therefore, the number of destinations that choose this type of promotion is greater and greater (Avery \& Ferraro, 2000; Busby \& Klug, 2001; Russell, 2002; Kaikati \& Kaikati, 2004; Croy, 2010). Films and TV series give destinations an incomparable opportunity to show their place in a natural way and that will be very helpful when helping spectators perceive the destination image according to what the destination wants to show.

We must bear in mind that not all destinations can compete for sun and beach, rural, sport or historical tourism, since they depend on their own resources. However, any destination can serve as a film set and therefore benefit from this type of tourism. Any destination can be perfect for locating a film or series, as each audio-visual project has different characteristics and directors and film productions look for different destinations, according to the requirements of the storyline. This offers a new form of promotion. Many companies choose the cinema or television series to carry out marketing campaigns and they make their products appear in those audio-visual projects in a natural way, as part of the scene or storyline (Morton \& Friedman, 2002). And in a similar way, more and more destinations are choosing to promote their product -the destination - through films (Croy, 2011). The fact that a film or series shows a destination from a positive perspective can lead to offer a differentiated image of it, to foster traveller loyalty, and to generate positive connotations with respect to the destination's image (Roesch, 2009).

Thus, films and TV series are a great opportunity to promote tourist destinations, but at the same time, each destination needs to be clear about the kind of image it wants to show, and it also must take care of the way the destination is promoted in the different cinematographic means (Hahm, \& Wang, 2011), since films have the potential to create both positive and 
negative impacts on tourism of a destination (Busby \& Klug, 2001; Hudson \& Ritchie, 2006). This presents both opportunities and challenges for Destination Management Organisations (DMOs), film commissions and film offices, and production companies (Morgan, \& Pritchard, 1998; Hudson, \& Ritchie, 2006; Cynthia, \& Beeton, 2009). DMOs usually take part in activities to promote the destination and they also often collaborate in the promotion of destinations through films and TV series (Vagionis \& Loumioti, 2011), especially in those destinations where there are no film commissions.

In short, by introducing destinations into cultural products such as films or series, they become part of people's daily lives. In this way, films and TV series are one of the main sources of tourist knowledge (Kim \& Richardson, 2003; Shani et al., 2009). Travellers' knowledge of both consolidated film destinations and other conventional destinations seems to be closely related to the success and popularity of series and films. The great social transcendence that some series currently reach makes knowledge and attractiveness quite variable.

There are multiple examples of films that have led to a considerable increase in the number of tourists (Bolan \& Williams, 2008). These cities that have been the subject of film locations have become more and more popular and have become destinations identified with the cinema. It would seem reasonable to affirm that these destinations will enjoy greater or lesser interest depending on the film activity generated there. In addition, the management of these destinations during and after the screening of the film or series is crucial. In order to contrast this reality and how these destinations and the intention to visit them have evolved in recent years, hypothesis 5 is proposed:

H5. The intention to visit film destinations has changed over the study period.

\section{Methodology}

As mentioned above, we have decided to carry out a comparative analysis. Comparison is a commonly used method in the research and analysis carried out in most areas of social, economic and political life (Baum, 1999) since the 1970s. As regards tourism studies, the comparative approach has been often used for improving understanding of the subject, and that allowed researchers to assess the significance, validity, and reliability of the outcomes, 
both quantitatively and qualitatively (Domínguez-Mujica, 2015). In this context, comparative studies may refer to a comparative research of tourists, a comparative research of places, or a comparative analysis of a tourism-related typology over time. A great deal of research uses a comparative method to outline similarities and differences among multiple features of destinations or tourists, on a longitudinal or structural basis (Baum, 1999). An overview of the latest academic studies highlights the importance of comparisons in tourism (Domínguez-Mujica, 2015), related to destinations and tourists, as well as to the development of a tourism typology. The data obtained were also subjected to descriptive and inferential analyses. The data analyses were performed using SPSS.26 and Statgraphics 18 software.

The analysis periods, 2014 and 2020, have been selected for different reasons. On the one hand, in 2014 many films or series were shot in Europe, so the phenomenon of film tourism reached more people. For example, Game of Thrones announced that it would be filming scenes of its next season in different parts of Europe and this aroused the interest of locals, tourists and also of the destination's managers who, that same year, 2014, carried out activities and strategies to take advantage of this phenomenon (Bolan \& Kearney, 2017). On the other hand, the health situation and mandatory quarantine in most countries have meant that the time people spend watching series and films has increased considerably during 2020 (Mikos, 2020; Ofcom, 2020). Therefore, these are two key years in which cinema has impacted our lives in different ways. Moreover, this 6-year framework for the period of analysis (2014-2020) is enough to show qualitative and/or quantitative differences over time in the cases that have been examined (Lind, Marchal \& Wathen, 2005; Gálvez-Rodríguez, Alonso-Cañadas, Haro-de-Rosario \& Caba-Pérez, 2020).

\subsection{Questionnaire design}

This questionnaire was designed in 2014 in a first study to find out the scope of film tourism at that time. Six years later, we wanted to repeat the same questionnaire to check how knowledge about film tourism and people's attitudes towards it have evolved. Therefore, to compare the situation in 2014 and the current situation, the same questionnaire was distributed to different people in 2020. 
The questionnaire was prepared after an in-depth review of the theoretical framework and the literature review, and it included two main sections to respond to the objectives:

1) The first section collected respondents' sociodemographic characteristics: gender, age, education, occupation, and country and region of residence.

2) The second section includes questions on film tourism: knowledge of the term, associated activities of film tourists, motivation, influence on the decision to travel and film tourism destinations. This section included yes/no questions and items with a 5-point Likert scale (from $1=$ strongly disagree to $5=$ strongly agree), based on previous questionnaires designed and tested by other authors and the literature on film tourism proposed by them (Macionis, 2004; Hudson \& Ritchie, 2006; Roesch, 2009).

Questions were included related to the association that travellers make with film destinations, and the main world destinations, in relation to the proposed objectives.

This questionnaire has been previously supervised to detect possible errors or comprehension difficulties. A pilot study was carried out on 20 people from various countries and comprehension difficulties were addressed. The questionnaire was designed in Spanish and English to reflect the linguistic needs of the respondents. The questionnaire can be found in the Appendix 1. The structured questionnaire was shared through a Google Form link that was distributed via social media, email and WhatsApp.

The variables used in the survey were measured using Likert scales, ranging from 1 to 5 points since the use of scales with a midpoint is more advisable (Garland, 1991). The same scale was used throughout the survey, to make it easier for respondents to answer and, at the same time, to try to avoid measurement errors.

\subsection{Sample description}

As mentioned above, the same survey was presented in two different years to be able to know the scope of film tourism at those two precise moments and, at the same time, to be able to perform a comparative analysis between the results of 2014 and 2020. A convenience sample, or non-probability sampling procedure, was used. Convenience method is suitable when it is difficult to obtain a complete sampling frame (Sirakaya, Uysal \& Yoshioka, 2003; Pérez, Mercadé-Melé \& Almeida-García, 2019; Almeida-García, Domínguez-Azcue, Mercadé-Melé, \& Pérez-Tapia, 2020). To improve the representativeness of the data, the 
sample selecting method used geographic, gender, and age quotas (Table 1). The questionnaires were distributed online between April 15 and April 30, 2014 and May 15 and 31 May 2020, since research has shown that online surveys get higher response rates and are cheaper to administer (Dillman, 2000). At the same time, the anonymity of online surveys also provides a comfort level that cannot be achieved with any other traditional method and responses are more honest (Rubin, 2000). A total of 301 valid questionnaires were obtained in 2014 with a sampling error of $5.6 \%$ and a confidence level of 95\%, and 587 valid questionnaires were obtained in 2020 with a sampling error of $4.0 \%$ and a confidence level of $95 \%$. In both cases, it was aimed at people over 18 years old and respondents were different. To maintain the quotas of visitors to the destination, part of the sample was collected outside Spain, namely, the United Kingdom, Italy, Germany, France, and the United States.

Table 1. Socio-demographic characteristics

\begin{tabular}{|c|c|c|}
\hline & 2014 survey & 2020 survey \\
\hline Universe & 18 year and more & 18 year and more \\
\hline Sample size & 301 & 587 \\
\hline Geographical area & $\begin{array}{l}\text { Europe }(82.1 \%) ; \\
\text { America }(17.9 \%)\end{array}$ & $\begin{array}{l}\text { Europe }(79.04 \%) \\
\text { America }(20.95 \%)\end{array}$ \\
\hline Gender & Male (55.1\%); Female $(44,9 \%)$ & Male (42.9\%); Female (57.1\%) \\
\hline Education & $\begin{array}{c}\text { Primary \& secondary }(41.5 \%) \\
\text { University \& postgraduate } \\
(58.5 \%)\end{array}$ & $\begin{array}{c}\text { Primary \& secondary }(15.16 \%) \\
\text { University \& postgraduate } \\
(84.84 \%)\end{array}$ \\
\hline Age groups & $\begin{array}{c}18-24(44.9 \%) ; 25-44(35.9 \%) ; \\
45-64(16.9 \%) \& 65+(2.7 \%)\end{array}$ & $\begin{array}{c}18-24(14.5 \%) ; 25-44(58.6 \%) ; 45- \\
64(22.7 \%) \& 65+(4.3 \%)\end{array}$ \\
\hline Sampling error & $5.60 \%$ & $4.07 \%$ \\
\hline Confidence level & $95 \%(p=q=0.5)$ & $95 \%(p=q=0.5)$ \\
\hline
\end{tabular}

Source: Own elaboration

\section{Results}

In this section, the empirical study of the research is carried out. First, the aim is to analyse whether the degree of knowledge of the term "film tourism" has changed over the study period, to provide an answer to the first hypothesis. Table 2 shows that there has been 
practically no change in the knowledge of film tourism over time $(x 2=0.01 ; p$-value $=0.971)$, and therefore hypothesis 1 is not verified. There has been practically no change in the knowledge of film tourism among respondents between 2020 and 2014. This aspect indicates that film knowledge is a ceteribus paribus concept over the study period.

Table 2. Degree of awareness of the term "film tourism" over time.

\begin{tabular}{ccccc}
\hline Año & Si & No & x2 & p-value \\
\hline 2014 & $55.70 \%$ & $44.30 \%$ & \multirow{2}{*}{0.01} & 0.971 \\
2020 & $55.50 \%$ & $44.50 \%$ & & \\
\hline \hline
\end{tabular}

Source: Own elaboration

After analysing the degree of knowledge of film tourism, the activities associated with the term are examined and whether they have changed. In this sense, a descriptive analysis of the items that are part of the activities related to film tourism is carried out. The scale used to measure the items is Likert-type, where 1 is Not at all and 5 is Very much. The test statistic used to contrast whether there are differences between these activities is the Wilcoxon Signed-Ranks test with continuity correction and, thus is used to analyse whether opinion has changed over time. Table 3 shows how there has been a change in terms of the activities associated with the term film tourism. The variables that show significant differences between 2014 and 2020 are "Filming locations", "Cities where large film studios are located" and "Film festivals". In the first two cases, it is currently more intensely associated; and on the contrary, in 2014, it was more intensely associated with film festivals.

Table 3. Activities related to "film tourism". Descriptive analysis and Wilcoxon SignedRanks test

\begin{tabular}{l|c|c|c|c|c|c|}
\hline & \multicolumn{2}{c|}{2014} & \multicolumn{2}{c|}{2020} & & \\
\hline & Mean & $\begin{array}{c}\text { Standard } \\
\text { deviation }\end{array}$ & Mean & $\begin{array}{c}\text { Standard } \\
\text { deviation }\end{array}$ & $\begin{array}{c}\text { Wilcoxon } \\
\text { Z }\end{array}$ & p-value \\
\hline Filming locations & 3.52 & 1.12 & 4.10 & 1.17 & -8.115 & 0.000 \\
\hline $\begin{array}{l}\text { Cities where large } \\
\text { film studios are }\end{array}$ & 2.68 & 1.19 & 3.10 & 1.31 & -4.445 & 0.001 \\
located & & 1.11 & 2.63 & 1.27 & -0.091 & 0.927 \\
\hline $\begin{array}{l}\text { Places linked to the } \\
\text { lives of actors and } \\
\text { directors }\end{array}$ & 2.61 & & & & & \\
\hline
\end{tabular}




\begin{tabular}{ll|c|c|c|c|c|c|}
\hline \multicolumn{2}{l|}{ Film festivals } & 3.84 & 1.07 & 3.51 & 1.31 & -3.237 & 0.001 \\
\hline $\begin{array}{l}\text { Film awards } \\
\begin{array}{l}\text { ceremonies } \\
\text { Goya) }\end{array}\end{array}$ & 3.24 & 1.29 & 3.13 & 1.37 & -1.014 & 0.311 \\
\hline
\end{tabular}

Source: Own elaboration

The previously described statistical analysis can be observed graphically. It can be seen how the location of filming and the cities where large studios are located have increased and, on the other hand, film festivals have decreased. Therefore, most of the activities associated with film tourism have changed, and hypothesis 2 is accepted for many of the activities.

Figure 2. Activities related to the term "film tourism". Graphic analysis

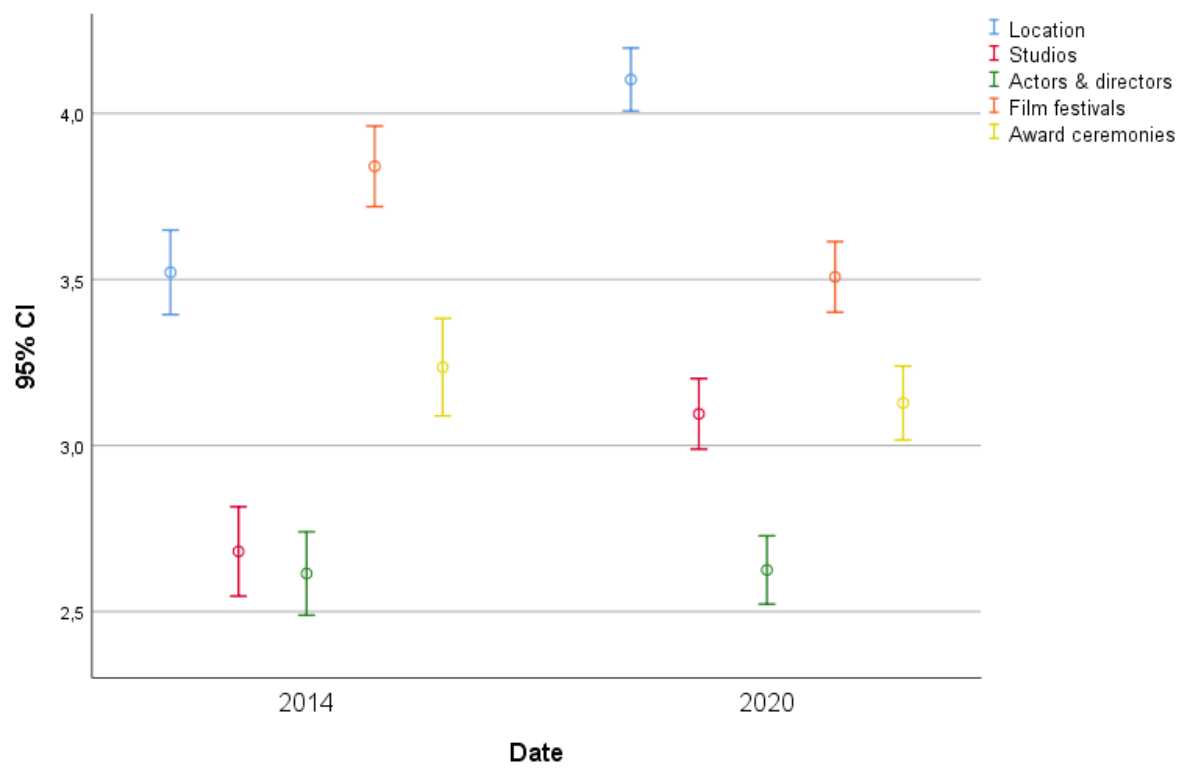

In Table 4, hypothesis 3 is tested, i.e., Film tourists' motivation to travel because of watching a film or series has changed over the study period. The relationship between motivation and travelling because of watching a film or series over the study period is verified, which verifies hypothesis $3(\times 2=11.424 ; p$-value=0.01). In addition, we can highlight that a part of the respondents who in 2014 said "Never, but I would like to", has now swelled the number of those who answer "Yes, but not as the main reason".

Table 4. Motivation to travel as a result of watching a film or series.

\begin{tabular}{|c|c|c|c|c|c|c|}
\hline Year & Never & $\begin{array}{c}\text { Never but I } \\
\text { would like } \\
\text { to }\end{array}$ & $\begin{array}{c}\text { Yes, but not as } \\
\text { the main } \\
\text { reason }\end{array}$ & $\begin{array}{c}\text { Yes, expressly } \\
\text { and exclusively }\end{array}$ & $x 2$ & $p$-value \\
\hline
\end{tabular}




\begin{tabular}{|l|l|l|l|l|l|l|}
\hline 2014 & $21.90 \%$ & $27.60 \%$ & $40.50 \%$ & $10.00 \%$ & 11.424 & 0.01 \\
\hline 2020 & $18.70 \%$ & $20.80 \%$ & $52.30 \%$ & $8.20 \%$ & & \\
\hline
\end{tabular}

Source: Own elaboration

Table 5 analyses the perceptions of individuals concerning the importance they attribute to films and series as a factor influencing their decision to visit a destination. There is a relationship in the type of influence depending on the year of the survey, and that verifies hypothesis 4 ( $\times 2=16.551 ; p$-value=0.002). In that sense, it should be noted that in 2020 twice the number of respondents consider that it has a greater influence on the travel decision.

Table 5. Influence of films and series on travel intention

\begin{tabular}{|c|c|c|c|c|c|c|c|}
\hline Year & Nothing & Little & Medium & Considerably & A lot & $x 2$ & p-value \\
\cline { 1 - 5 } 2014 & $2.70 \%$ & $23.60 \%$ & $30.60 \%$ & $33.90 \%$ & $9.30 \%$ & 16.551 & 0.002 \\
\cline { 1 - 5 } 2020 & $4.30 \%$ & $17.20 \%$ & $30.30 \%$ & $30.20 \%$ & $18.10 \%$ & & \\
\hline
\end{tabular}

Source: Own elaboration

Lastly, Table 6 examines the places respondents would like to travel to as a consequence of watching a film or series (hypothesis 5).

Table 6. Destinations respondents would like to travel to as a consequence of watching a film or series

\begin{tabular}{|l|r|r|r|c|}
\hline Destinations & $2014(\%)$ & $2020(\%)$ & Increase (\%) & p-value \\
\hline New York & 50.17 & 32.77 & -34.68 & 0.000 \\
\hline Paris & 24.58 & 27.50 & 11.88 & 0.350 \\
\hline London & 18.94 & 29.20 & 54.21 & 0.000 \\
\hline Rome & 16.28 & 30.73 & 88.77 & 0.000 \\
\hline Barcelona & 3.65 & 18.34 & 401.74 & 0.000 \\
\hline Berlin & 10.30 & 16.64 & 61.55 & 0.011 \\
\hline Madrid & 1.00 & 23.43 & 2250.76 & 0.000 \\
\hline New Zealand & 3.99 & 20.37 & 411.04 & 0.000 \\
\hline Egypt & 10.63 & 17.49 & 64.49 & 0.006 \\
\hline
\end{tabular}




\begin{tabular}{|l|r|r|r|r|}
\hline Spain & 9.30 & 26.99 & 190.20 & 0.000 \\
\hline
\end{tabular}

Source: Own elaboration

Table 6 shows how destinations where respondents would like to travel to have changed, except for Paris, which does not show statistically significant differences. In 2020 there has been an increase in almost all places ( $p$-value < 0.05) except for New York where it has lost interest in favour of the others. Therefore, almost all film destinations have experienced a change over time, thus verifying hypothesis 5 .

\section{Discussion}

This longitudinal study contributes to the proposed purpose since it describes the development of film tourism in the last 6 years, suggesting very interesting facts and trends that could lead this type of tourism to further growth at a very high level.

In relation to the first hypothesis $(\mathrm{H} 1)$, regarding the knowledge of the term "film tourism", the period of analysis (2014-2020) is maintained. It is a remarkable knowledge (55.6\% mean) and it may have reached the maximum of the potential tourist interested in this product. The fact that there are no differences regarding the term enables us to say that we are dealing with a ceteribus paribus context, i.e., the effect of all other variables is not influenced by a greater or lesser knowledge of the term. Change in the behaviour of tourists is due to other reasons resulting from new forms of interconnectivity through social networks, opinion forums, etc.

This hypothesis was based on the process of knowledge transfer. Since the concept has been the subject of analysis in many previous research studies and its visibility and importance has grown considerably in academic research, it was assumed that it would be accompanied by a greater degree of knowledge and visibility in society. However, this is not the case. Arias-Pérez and Aristizabal-Botero (2011) state that scientific knowledge reaches society by generating an economic, social and knowledge impact. That is partly supported since, although the impact on knowledge is not verified, the economic and social impacts are confirmed. Figures published by official agencies point to a growth of this type of tourism (TCI Research, 2018). 
Although the aforementioned awareness of the term "film tourism" has not increased, the predisposition to travel to places that have been seen in a film or series has grown $(\mathrm{H} 2)$. The activities that have the most positive impact on the film tourism travel trend are related to filming locations and established film destinations, while film festivals and film world galas have decreased. That could be since, in 2020, film festival and ceremonies have been severely affected by Covid-19 when health measures in many countries have prevented gatherings of people and banned attendance at large events.

In 2014, the main activity related to film tourism was attending film festivals (3.84 points out of 5), while filming locations and cities where film studios are located were associated to a lesser extent (3.52 and 2.68 respectively). That has changed during the study period. In 2020 the main activity related to film tourism was the location of film shoots (4.10). The greater valuation of filming locations and consolidated destinations is in line with the trends analysed by recent studies (Araújo, Fraiz \& De Carlos, 2021).

The results also indicate a significant change in terms of visiting a destination motivated by seeing it in a film or series (H3). In 2014, 49.5\% of respondents did not yet travel to any destination after seeing it in a film or series. In 2020, that percentage decreased to $39.5 \%$. That decrease has come along with an increase in the number of tourists who have done so, but not as the main reason. There is, therefore, a greater predisposition to visit film destinations in recent years. That is a good symptom that reflects the general trend in this type of tourism. On the other hand, for the remaining $50 \%$ of respondents who have travelled for cinematographic reasons, the results show that the group that does so for secondary reasons is growing (from $40.5 \%$ to $52.3 \%$ ), and that the group that does so as the main reason is decreasing (from 10\% to $8.2 \%$ ). The percentage of the latter group is in line with the figures provided by the study by Araújo, et el., (2021) for Spain (10.4\%), and other studies (Rittichainuwat \& Rattanaphinanchai, 2015).

That is related to what Macionis (2004) states, although the trend observed in the present study differs in some aspects. Macionis (2004) distinguish between serendipitous film tourists -they just happen to be in a destination portrayed in a film; general film tourists even if they are not specifically drawn to a film location, they participate in film tourism activities; and specific film tourists - they actively seek out places that they have seen in 
films). Given our results and based on the theory proposed by Macionis (2004), it can be affirmed that interest in film tourism and film destinations is growing among the general film tourists and not among tourists who travel specifically for film purposes. The number of specific film tourists is marginal. Young and Young (2008) found that $20 \%$ of their respondents related United Kingdom to a film but only $2 \%$ of them had become tourists because of it. Similarly, Busby and Klug (2001) found that only 5.3\% were motivated by films, while Macionis and Sparks (2009) found that specific film tourists accounted for only $4 \%$ of their sample. $4 \%$ of respondents in the Di Cesare, D'Angelo and Rech (2009) study acknowledged the influence of films on their decision to travel to a destination.

Regarding the influence that films and series could have on the decision to visit a destination, the perception or opinion of the respondents is clear $(\mathrm{H} 4)$. Regarding general data, without analysing its evolution, it should be noted that between $20 \%$ and $25 \%$ of respondents consider that cinema has no or little influence on the decision to travel, while around $75 \%$ of respondents think that it has a medium, high or very high influence. If we analyse the trend over the years, it can be noted that the group that perceives films and series as having a medium influence on their decisions has remained constant (30\%). On the other hand, those who have experienced the greatest growth have been those who consider that the influence is very high (growing by $9 \%$ ). That is another sign of the magnitude of this type of tourism.

Regarding changes in the intention to visit film destinations $(\mathrm{H} 5)$, it can be observed that there have been substantial changes during the study period. In general, all destinations mentioned by respondents have increased significantly, except for Paris, which has not changed, and New York, which has decreased. We believe that the awareness and diffusion of series and movies related to New York have slowed down, after numerous successes linked to series (Sex and the City, Girls, etc.), so that there has been a clear decrease in the intention to visit. Madrid is the one that shows the highest growth along with Barcelona. In the case of Madrid, it seems that this knowledge is linked to the series "La Casa de Papel", distributed by Netflix (Diario de Sevilla, 2021).

\section{Conclusions}

\subsection{Consideration}


During the year 2020 and 2021 Covid-19 has affected the consumption patterns of millions of people around the world. Mobility limitations, border closures, elimination of air connections, etc., have intensely affected tourism activity since it is an activity that relies closely on mobility (Škare, Soriano \& Porada-Rochoń, 2021). Consequently, film tourism has also been significantly affected, as well as most tourist activities. On the other hand, the consumption of audiovisual products increased notably in 2020, due to the confinements that various countries and cities faced, the difficulties people had in engaging in leisure activities outside their homes, and the growth of television operators and platforms. The aforementioned limitations and the easy accessibility of audiovisual services have increased the domestic consumption of audiovisual products (Mikos, 2020; Sheth, 2020). It is likely that after the pandemic, the increase in individual or domestic consumption of audiovisual products will continue, at the expense of activities that were already decreasing, such as attending movie theatres (Mikos, 2020; Sheth, 2020).

\subsection{Practical implications}

The pandemic has increased the audiovisual content consumption based on digital platforms (Domínguez et al., 2021). This change has come hand in hand with an increase in the number of film and series-based travels, as well as a greater awareness of destinations associated with series, film shoots and film studios.

The increase in promotion linked to content broadcasting platforms ( $\mathrm{HBO}$, Netflix, Amazon, etc.) and the impact of Covid-19, which has reinforced this trend, seems to lessen the importance of film festivals and awards ceremonies as elements in the creation of destination image. Those events were fundamental to the prestige of the destinations, and tourism managers tried their best to organize some of those festivals. It seems that the new trends that destination managers should pay attention to are related to positioning destinations within the series linked to platforms, with the support of social networks that accompany the creation and post-production of the series by creating content.

The changes experienced in the motivations and behaviours of the demand in film destinations forces destination managers to improve their controlling and promotion instruments. For this reason, the role of the cinematographic commission and the other local agencies is fundamental. This promotion carried out by film commissions is essential for film 
productions to decide to shoot at their destination (Hudson \& Ritchie, 2006). The collaboration between local government and the different agencies is essential to reach agreements. Some factors influence the level of success in transforming cinema into promotional tourism resources: (i) characteristics of the destination; (ii) factors directly related to the film, such as the importance of the director, the cast or the plot; (iii) and the promotional activities carried out by the destination (social network, agreements with platforms); iv) management capacity of film commissions and other local agencies. Those activities need to be carried out before, during and also after the production of the film or series (Figure 3).

Figure 3. Activities to carry out by the destination
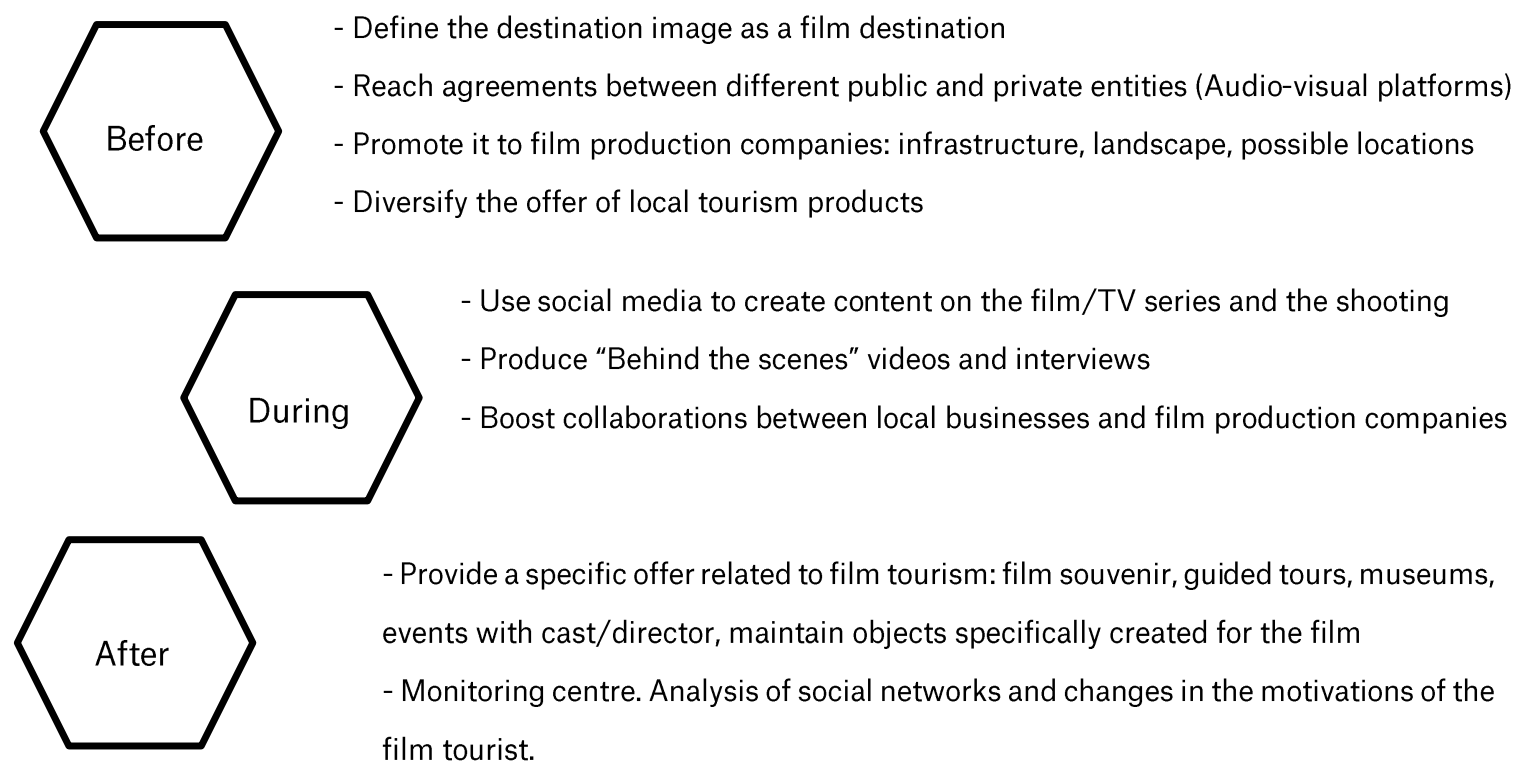

Source: Hudson and Ritchie, 2006 and own elaboration 


\subsection{Limitations and future research}

Despite the contribution of this research both at the academic and destination management levels, some limitations should be mentioned. Firstly, the study is based on a strictly quantitative methodology, and that is necessary for a longitudinal study. But it could be completed with a qualitative analysis to achieve a deeper understanding of the facts and perspective presented. Another limitation is due to the inclusion of cities that are a priori associated with film destinations, and not including the series or films themselves that have caused this fact. It would have been interesting to relate both (cause-effect).

Future lines of research could replicate this study across continents, i.e., in a cross-sectional manner, rather than a longitudinal analysis as here. There may be cultural differences regarding film tourism. The film tourist trends detected invite us to carry out future research related to the study of the loyalty and attraction of segments according to films and series. In this sense, tourism segmentation studies allow us to better adapt the tourism offer according to the different profiles that visit the destination, as well as its audiovisual offer (Tkaczynski, Rundle-Thiele \& Beaumont, 2010).

\section{Bibliographic references}

Almeida-García, F., Domínguez-Azcue, J., \& Mercadé-Melé P. (2017) Image Analysis of a Tourist Destination. In: Correia A., Kozak M., Gnoth J., Fyall A. (eds) Co-Creation and WellBeing in Tourism. Tourism on the Verge. Springer, Cham.

Almeida-García, F., Domínguez-Azcue, J., Mercadé-Melé, P., \& Pérez-Tapia, G. (2020). Can a destination really change its image? The roles of information sources, motivations, and visits. Tourism Management Perspectives, 34, 100662.

Arias-Pérez, J. E. y Aristizábal-Botero, C. A. (2011). Transferencia del conocimiento orientada a la innovación social en la relación ciencia-tecnología y sociedad. Revista científica Pensamiento y Gestión, 31, 137-166.

Avery, R. \& Ferraro, R. (2000). Verisimilitude or advertising? Brand appearances on primetime television, The Journal of Consumer Affairs. 34(2), 217-244. 
Araújo, N., Fraiz, J. A. \& de Carlos, P. (2021). Film tourism in Spain: Destination awareness and visit motivation as determinants to visit places seen in TV series. European Research on Management and Business Economics, 27(1), 100135.

Baloglu S (2000). A Path-Analytical Model of Visitation Intention Involving Information Sources, Socio-Psychological Motivations and Destinations Images. In: A. Woodside, G. Crouch, J. Mazanec, M. Oppermann and M. Sakai, (Eds.), Consumer Psychology of Tourism Hospitality and Leisure (pp. 63-90). New York: CABI Publishing.

Bang, Y. Y., Joo, Y., Seok, H., \& Nam, Y. (2021). Does K-pop affect Peruvians' Korean images and visit intention to Korea? Current Issues in Tourism, 1-16

Baum, T. (1999). Themes and Issues in Comparative Destination Research: The Use of Lesson-Drawing in Comparative Tourism Research in the North Atlantic. Tourism Management 20:627-633.

Beeton S. (2005). Film Induced Tourism, Clevedon, Channel View Publications.

Beeton, S., \& Cavicchi, A. (2015). Not Quite Under the Tuscan Sun... the Potential of Film Tourism in Marche Region. Almatourism - Journal of Tourism, Culture and Territorial Development, 6(4), 146-160.

Bieger T, Laesser C (2004). Information Sources for Travel Decisions: Toward a Source Process Model. Journal of Travel Research, 42(4): 357-371.

Blanchet, C., \& Fabry, N. (2020). Influence of new cinematographic and television operators on the attractivity of tourist destinations. Journal of Tourism Futures, 6(3), 219-222.

Bolan, P., \& Kearney, M. (2017). Exploring film tourism potential in Ireland: From Game of Thrones to Star Wars. In Unknown Host Publication Universidade de Aveiro

Bolan, P., \& Williams, L. (2008). The role of image in service promotion: focusing on the influence of film on consumer choice within tourism. International Journal of Consumer Studies, 32(4), 382-390.

Busby, G. \& Klug, J. (2001). Movie Induces Tourism: The challenges of measurement and other issues. Journal of Vacation Marketing, 7, 316-332. 
Butler, R. (1990). The influence of the media in shaping international tourist patterns. Tourism Recreation Research. 15(2), 46-53.

Cardoso, L., Estêvão, C., Fernandes, C. \& Alves, H. (2017). Film induced tourism: a systematic literature review. Tourism \& Management Studies, 13(3), 23-30.

Chen, C. Y. (2018). Influence of celebrity involvement on place attachment: role of destination image in film tourism. Asia Pacific Journal of Tourism Research, 23(1), 1-14.

Cynthia, D., \& Beeton, S. (2009). Supporting Independent Film Production Through Tourism Collaboration. Tourism Review International, 13, 113-119.

Connell, J. (2012). Film tourism: Evolution, progress and prospects, Progress in Tourism Management paper. Tourism Management, 33(5), 1007-1029.

Connell, J., \& Meyer, D. (2009). Balamory revisited: An evaluation of the screen tourism destination-tourist nexus. Tourism Management, 30(2), 194-207.

Croy, W. (2010). Planning for film tourism: Active destination image management. Tourism and Hospitality Planning \& Development, 7(1), 21-30.

Croy, G. (2011). Film tourism: sustained economic contributions to destinations. Worldwide Hospitality and Tourism Themes, 3(2), 159-164.

Di Cesare, F., D'Angelo, L., \& Rech, G. (2009). Films and Tourism: Understanding the Nature and Intensity of their Cause-Effect Relationship. Tourism Review International, 13(2), 103111.

Diario de Sevilla (2021.05.19). Cómo las series y películas españolas atraen turistas y generan afinidad cultural, Spain (Access 19.05.2021). Retrieved from: https://www.diariodesevilla.es/television/peliculas-series-espanolas-turistas-afinidadcultural_0_1575444782.html

Dillman, D. A. (2000). Mail and Internet Surveys: The Tailored Design Method, 2nd ed. New York: John Wiley \& Sons.

Domínguez-Azcue, J., Almeida-García, F., Pérez-Tapia, G., Cestino-González, E. (2021). Films and Destinations-Towards a Film Destination: A Review. Information, 12, 39 
Domínguez-Mujica, J. (2015). Comparative study, tourism. In Encyclopedia of Tourism. Springer International Publishing, Switzerland. J. Jafari, H. Xiao (eds).

Eagles, P. (2000). Information Sources for Planning and Management. In The Encyclopedia of Ecotourism (pp. 611-626). New York: CABI Publishing.

Gálvez-Rodríguez, M. del M., Alonso-Cañadas, J., Haro-de-Rosario, A., \& Caba-Pérez, C. (2020). Exploring best practices for online engagement via Facebook with local destination management organisations (DMOs) in Europe: A longitudinal analysis. Tourism Management Perspectives, 34, 100636.

Garland, R. (1991). The mid-point on a rating scale: Is it desirable? Marketing Bulletin, 2, 6670.

Gartner, W. (1993). Image Formation Process. Journal of Travel and Tourism Marketing. 2, 191-216.

Grihault, N. (2003) 'Film Tourism - The Global Picture', Travel \& Tourism Analyst 5: 1-22.

Gyimóthy, S., Lundberg, C., Lindström, K., Lexhagen, M. \& Larson, M. (2015). Popculture tourism research manifesto. In: D. Chambers and T. Rakić (eds.), Tourism Research Frontiers: Beyond the Boundaries of Knowledge, 20, 13-26.

Hahm, J., Upchurch, R. \& Wang, Y. (2008). Millennial students, movies, and tourism. Tourism Analysis, 13(2), 189-204

Hahm, J. \& Wang, Y. (2011). Film-induced tourism as a vehicle for destination marketing: is it worth the efforts? Journal of Travel \& Tourism Marketing, 28(2), 165-179.

Hao, X. \& Ryan, C. (2013). Interpretation, film language and tourist destinations: A case study of Hibiscus Town, China. Annals of Tourism Research, 42(2), 334-358.

Hosany, S., Buzova, D., \& Sanz-Blas, S. (2020). The influence of place attachment, ad-evoked positive affect, and motivation on intention to visit: Imagination proclivity as a moderator. Journal of Travel Research, 59(3), 477-495

Hudson, S. \& Ritchie, J. R. B. (2006). Promoting Destinations via Film Tourism: An Empirical Identification of Supporting Marketing Initiatives. Journal of Travel Research, 44, 387-396. 
Jang, S., B. Bai, C. Hu, and C. M. E. Wu. 2009. "Affect, Travel Motivation, and Travel Intention: A Senior Market." Journal of Hospitality \& Tourism Research 33 (1): 51-73.

Kaikati, A. \& Kaikati, J. (2004). Stealth marketing: How to reach consumers surreptitiously. California Management Review, 46(4) 6-22.

Kim, S., Kim, S., \& Han, H. (2019). Effects of TV drama celebrities on national image and behavioral intention. Asia Pacific Journal of Tourism Research, 24(3), 233-249.

Kim, S., Kim, S. \& King, B. (2018). Nostalgia film tourism and its potential for destination development. Journal of Travel \& Tourism Marketing, 71-87.

Kim, H. \& Richardson, S. (2003). Motion picture impacts on destination images. Annals of Tourism Research, 30, 216-237.

Lee, S. T. (2021). Film as cultural diplomacy: South Korea's nation branding through Parasite (2019). Place Branding and Public Diplomacy, 1-12.

Li, M., \& Cai, L. A. (2012). The effects of personal values on travel motivation and behavioral intention. Journal of Travel Research, 51(4), 473-487.

Li, M., L. A. Cai, X. Y. Lehto, and J. Huang. 2010. “A Missing Link in Understanding Revisit Intention-The Role of Motivation and Image." Journal of Travel \& Tourism Marketing 27 (4): $335-48$

Li, S., Li, H., Song, H., Lundberg, C., \& Shen, S. (2017). The economic impact of on-screen tourism: The case of The Lord of the Rings and the Hobbit. Tourism Management, 60, 177187.

Lind, D., Marchal, W. and Wathen, S. (2005) Statistical Techniques in Business \& Economics. McGraw-Hill Irwin, New York.

Liu, Y., Chin, W. L., Nechita, F., \& Candrea, A. N. (2020). Framing Film-Induced Tourism into a Sustainable Perspective from Romania, Indonesia and Malaysia. Sustainability, 12(23), 9910.

Macionis, N. (2004). Understanding the film-induced tourist. In International tourism and media conference proceedings (Vol. 24, pp. 86-97). Tourism Research Unit, Monash University: Melbourne, Australia. 
Macionis, N., \& Sparks, B. (2009). Film-induced Tourism: An Incidental Experience. Tourism Review International, 13(2), 93-101.

Martin-Fuentes, E., Nieto-Ferrando, J., Marine-Roige, E. \& Ferrer-Rosell, B. (2020). From Blockbuster to Neighbourhood Buster: The Effect of Films on Barcelona. Sustainability, 12(6):2290.

Martin-Jones, D. (2014). Film tourism as heritage tourism: Scotland, diaspora and The Da Vinci Code (2006). New Review of Film and Television Studies, 12(2), 156-177.

McKercher, B. \& Cross, H. (2002). Cultural tourism: the partnership between tourism and cultural heritage; The Haworth Press, USA

Mikos, L. (2020). Film and Television Production and Consumption in Times of the COVID19 Pandemic-The Case of Germany. Baltic Screen Media Review, (8), 30-34.

Morgan, N.; Pritchard. (1998). A. Tourism promotion and power: Creating images, creating identities; John Wiley \& Sons Ltd.: Hoboken, NJ, USA.

Morton, C. R., \& Friedman, M. (2002). "I Saw it in the Movies": Exploring the Link between Product Placement Beliefs and Reported Usage Behavior. Journal of Current Issues \& Research in Advertising, 24(2), 33-40.

Nakayama, C. (2020). Film-induced Tourism Studies on Asia: A Systematic Literature Review. Tourism Review International, 25(1), 63-78.

Ng, T. M., \& Chan, C. S. (2020). Investigating film-induced tourism potential: The influence of Korean TV dramas on Hong Kong young adults. Asian Geographer, 37(1), 53-73.

O'Connor, N., Flanagan, S. \& Gilbert, D. (2008). The integration of film-induced tourism and destination branding in Yorkshire, UK. International Journal of Tourism Research, 10, 423437.

Ofcom (05.08.2020). Media Nations 2020. (Access: 03.03.2021). Retrieved from: https://www.ofcom.org.uk/research-and-data/tv-radio-and-on-demand/media-nationsreports/media-nations-2020

Özdemir, G., \& Adan, Ö. (2014). Film tourism triangulation of destinations. Procedia-Social and Behavioral Sciences, 148, 625-633. 
Papathanassis, A. (2011). The long tail of tourism: Holiday niches and their impact on mainstream tourism; Deutsche Nationalbibliothek, Germany.

Pérez, G., Mercadé-Melé, P., \& Almeida-García, F. (2019). Corporate image and destination image: the moderating effect of the motivations on the destination image of Spain in South Korea. Asia Pacific Journal of Tourism Research, 24(1), 70-82.

Pratt, S. (2015). The Borat Effect: Film-Induced Tourism Gone Wrong. Tourism Economics, 21(5), 977-993.

Ramkissoon, H., \& Uysal, M. S. (2011). The effects of perceived authenticity, information search behaviour, motivation and destination imagery on cultural behavioural intentions of tourists. Current Issues in Tourism, 14(6), 537-562

Riley, R. \& Van Doren, C. (1992). Movies as tourism promotion. Tourism Managemente, 13(3), 267-274.

Rittichainuwat, B. \& Rattanaphinanchai, S. (2015). Applying a mixed method of quantitative and qualitative design in explaining the travel motivation of film tourists in visiting a filmshooting destination. Tourism Management, 46, 136-147.

Roesch, S. (2009). The Experiences of Film Location Tourists. In: Aspects of Tourism. Channel View Publications, 248.

Rubin, J. (2000). “Online Marketing Research Comes of Age." Brandweek, 41 (42): 26

Russell, J. (2002). Investigating the effectiveness of product placements in television shows: The role of modality and plot connection congruence in brand memory and attitude. Journal of Consumer Research. 29(3) 306-319.

Sirakaya, E., Uysal, M., \& Yoshioka, C. F. (2003). Segmenting the Japanese tour market to Turkey. Journal of Travel Research, 41(3), 293-304.

Shani, A., Wang, Y., Hudson, S.; \& Gil, S. (2009). Impacts of a historical film on the destination image of South America. Journal of Vacation Marketing. 15(3), 229-242.

Sheth, J. (2020). Impact of Covid-19 on consumer behavior: Will the old habits return or die? Journal of Business Research, 117, 280-283. 
Škare, M., Soriano, D. R., \& Porada-Rochoń, M. (2021). Impact of COVID-19 on the travel and tourism industry. Technological Forecasting and Social Change, 163, 120469.

TCl Research (2018). 80 million international travellers. [02.11.2020]. Retrieved from: http://x|4z.mj.am/nl2/x|4z/lgs45.html?hl=fr

Tkaczynski, A., Rundle-Thiele, S., \& Beaumont, N. (2010). Destination segmentation: A recommended two-step approach. Journal of Travel Research, 49(2), 139-152.

Tkalec, M., Zilic, I., \& Recher, V. (2017). The effect of film industry on tourism: Game of Thrones and Dubrovnik. International Journal of Tourism Research, 19(6), 705-714

Um, S., \& Crompton, J.L. (1990). Attitude Determinants in Tourism Destination Choice. Annals of Tourism Research. 17(3): 432-448.

Vagionis, N.; Loumioti, M. (2011). Movies as a tool of modern tourist marketing. Tourismos: An international multidisciplinary journal of tourism, 6(2) 353-362.

Wong, J. Y., \& Lai, T. C. (2015). Celebrity attachment and behavioral intentions: The mediating role of place attachment. International Journal of Tourism Research, 17(2), 161-170

Xu, M., Kim, S., \& Reijnders, S. (2020). From food to feet: Analysing A Bite of China as foodbased destination image. Tourist Studies, 20(2), 145-165.

Yoon, Y., \& Uysal, M. (2005). An examination of the effects of motivation and satisfaction on destination loyalty: a structural model. Tourism management, 26(1), 45-56

Young, A. \& Young, R. (2008) Measuring the Effects of Film and Television on Tourism to Screen Locations: A Theoretical and Empirical Perspective, Journal of Travel \& Tourism Marketing, 24:2-3, 195-212. 